Halaman: 58-64

\title{
Pemanfaatan Tumbuhan Obat Masyarakat Marind yang Bermukim di Taman Nasional Wasur, Merauke
}

\author{
DWI HARYANTO ${ }^{1}$ ROSYE H.R. TANJUNG2*, DAN KONSTANTINA M.B. KAMEUBUN1 \\ 1PS. Pendidikan Biologi, FKIP Universitas Cenderawasih,Jayapura-Papua \\ 2Jurusan Biologi FMIPA Universitas Cenderawasih, Jayapura-Papua
}

Diterima: tanggal 19 Januari 2009 - Disetujui: 7 Mei 2009

(C) 2009 Jurusan Biologi FMIPA Universitas Cenderawasih

\begin{abstract}
Study on the used of medicinal plants by Marind people who lived at Wasur National Park, Merauke was conducted by using descriptive methods which include observation, interview, documentation, literature review techniques, as well as emic and ethic approaches. During the study there were 46 species which belong to 26 families plants found as medicinal plants used by Marind people to cure about 30 diseases. Among 46 species, there were 7 potential medicinal plant species which known and used by most Marind people. The seven potential medicinal plant species were Ipomoea triloba L., Bauhinia sp., Pittosporum sp., Kingiodendron platycarpum Bent., Sophora tool mentosa L.Cyrtandra sp., dan Tinopspora disstiflora L. Part of plant used vary from leaf, root, bark, fruit and other part of plant. Compare to other part of plant, leaf was the most common used as traditional medicinal plant.
\end{abstract}

Key words: traditional medicinal plant, Marind people, Wasur National Park

\section{PENDAHULUAN}

Kabupaten Merauke memiliki dua kawasan hutan lindung, yaitu Taman Nasional Wasur dan Cagar Alam Kumbe. Taman Nasional Wasur terletak di bagian sudut tenggara Provinsi Papua dengan luas kira-kira 413.810 ha (Dinas Kehutanan Kabupaten Merauke, 1999). Suku Marind merupakan salah satu suku terbesar yang menempati pantai selatan Papua yakni di sepanjang pesisir pantai dari muara Sungai Digul (Pulau Yos Sudarso) dan seluruh daerah pedalaman sampai daerah hulu sungai (Maro, Kumbe, Bian, Bulaka) hingga Sungai Fly dibagian

\footnotetext{
*Alamat Korespondensi:

Laboratorium Biologi FMIPA, Jln. Kamp Wolker, Kampus Baru UNCEN-WAENA, Jayapura Papua. 99358 Telp: +62967572115 .

email: hefmyca@yahoo.com.
}

perbatasan Papua New Guinea. Salah satu daerah penyebarannya adalah Taman Nasional Wasur dan Cagar Alam Kumbe (Dinas Kehutanan Kabupaten Merauke, 1999). Secara geografis Taman Nasional Wasur terletak di bagian tenggara pulau Papua, yang berada pada koordinat 140027'-14102' BT dan 805'-907' LS (Badan Pusat Statistik, 2002).

Keberadaan suku-suku di pedalaman sangat berpengaruh terhadap pemanfaatan lingkungan alamnya dalam kehidupan sehari-hari. Diantaranya adalah pemanfaatan tumbuhan hutan sebagai bahan obat tradisional. Bahkan hingga zaman modern saat ini konsep back to nature kembali mengemuka, seiring dengan pentingnya pengelolaan dan pemanfaatan lingkungan dalam memenuhi kehidupan seharihari termasuk memelihara kesehatan. Tumbuhan yang telah dibudidayakan kurang lebih 940 jenis digunakan sebagai obat tradisional (Hernani \& 
Syukur, 2002). Lebih lanjut Hernani \& Syukur (2002) mengemukakan bahwa pemakaian tumbuhan obat akhir-akhir ini meningkat sejalan dengan berkembangnya industri jamu atau obat tradisional, farmasi, kosmetik, makanan, dan minuman. Tumbuhan obat yang sering digunakan, biasanya dalam bentuk simplisia (bahan yang telah dikeringkan dan belum mengalami pengolahan apapun). Simplisia tersebut dapat berasal dari akar, daun, bunga, biji, buah, terna dan kulit. Sedangkan Rahardi (1996), mengemukakan bahwa tumbuhan obat adalah tumbuhan yang salah satu, beberapa atau seluruh bagian tumbuhan tersebut mengandung zat atau bahan aktif yang berkhasiat bagi kesehatan (penyembuhan penyakit). Penggunaan atau pengobatan secara tradisional semakin disukai karena pada umumnya kurang menimbulkan efek samping seperti halnya pada obat-obatan dari bahan kimia (Tampubolon 1998 dalam Rully, 2001).

Dalam kawasan Taman Nasional berdiam penduduk asli yang memiliki hak ulayat atas tanah tersebut. Penduduknya yang suku Marind terdiri dari beberapa sub-suku, yakni Marind Kanum, Marind Kondo dan Marind Marori Men-Gey, yang tersebar di 12 kampung (Dinas Kehutanan Kabupaten Merauke, 1999). Penyebarannya dari pesisir pantai hingga dataran tinggi. Pada umumnya aktivitas masyarakat sangat erat dengan lingkungan sekitarnya. Mereka juga memanfaatkan sumber daya alam yang ada disekitarnya terutama tumbuhan yang sering dijadikan sebagai bahan obat untuk mengobati penyakit yang mereka derita walaupun sudah ada Puskesmas di daerah itu. Data mengenai tumbuhan yang digunakan sebagai obat pada masyarakat Marind di Taman Nasional Wasur masih sangat kurang bahkan belum dilakukan penelitian tentang inventarisasi jenis-jenis tumbuhan obat pada Masyarakat Marind di Wilayah

Gambar 1. Sketsa Lokasi Penelitian
Taman Nasional Wasur, Kabupaten Merauke.

Tujuan dari penelitian ini adalah untuk mengetahui jenis tumbuhan, cara penggunaan, bagaimana pengetahuan masyarakat dan upaya untuk melestarikan tumbuhan yang dimanfaatkan sebagai obat oleh masyarakat Marind yang bermukim di Taman Nasional Wasur, Merauke.

\section{METODE PENELITIAN}

\section{Tempat dan Waktu Penelitian}

Penelitian ini dilaksanakan di Taman Nasional Wasur Distrik Merauke Kabupaten Merauke (Gambar 1), dari bulan September 2005 sampai Januari 2006. Penelitian berlangsung di 7 kampung, masing-masing adalah Nasem; Kuler; Onggaya; Wasur; Yanggandur; Rawa Biru; Sota.

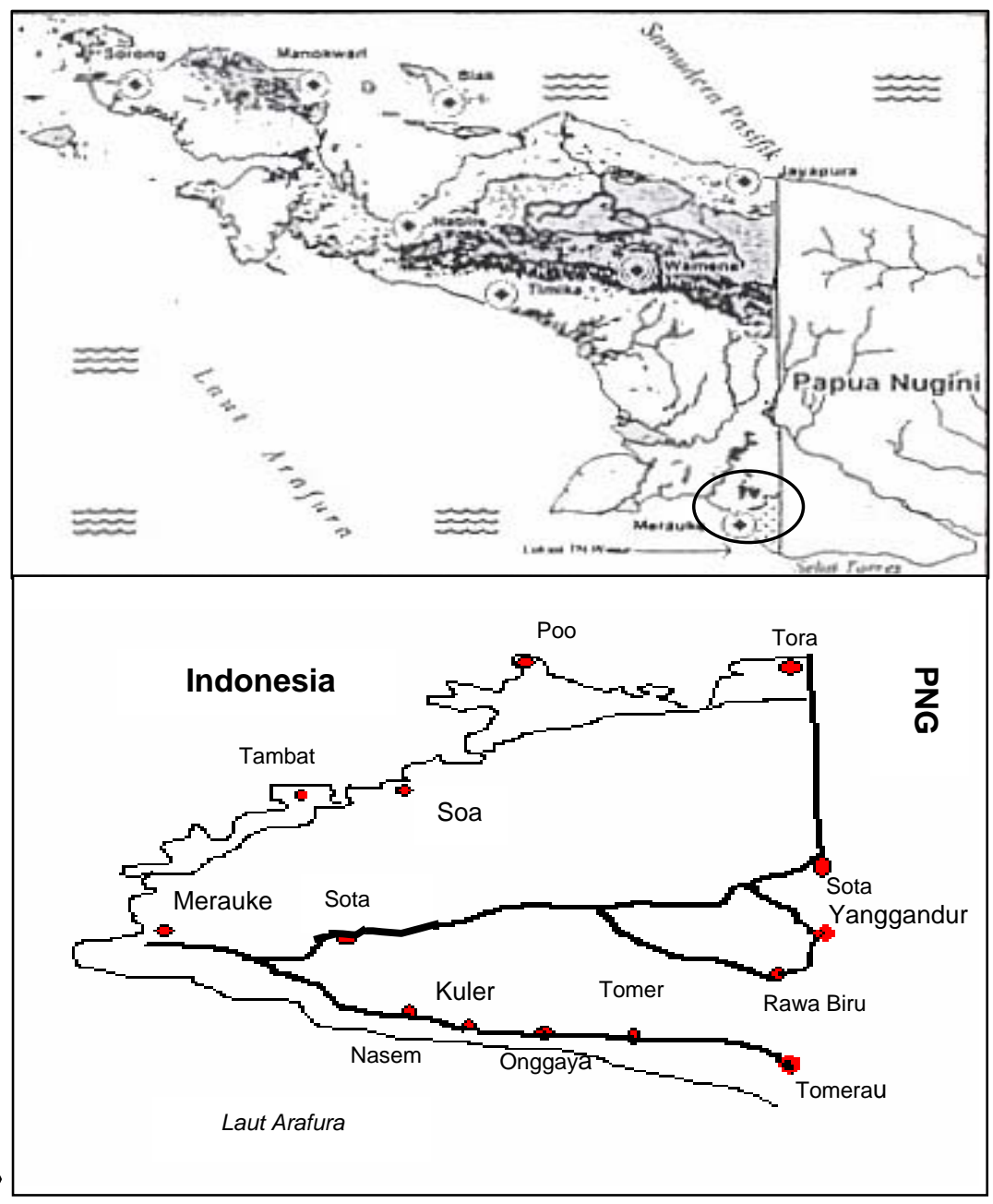




\section{Metode Penelitian}

Metode yang digunakan dalam penelitian ini adalah metode deskriptif kualitatif, melalui pendekatan emik dan etik. Pendekatan emik digunakan dengan maksud untuk mendapatkan data mengenai pengetahuan masyarakat tentang obyek yang sedang diamati menurut pemahaman dan bahasa mereka tanpa harus menguji kebenarannya, sedangkan pendekatan etik digunakan dalam menganalisis data dari pengetahuan masyarakat tersebut secara ilmiah. Pendekatan yang digunakan pada umumnya menggunakan RRA (Rapid Rural Appraisal), observasi dan wawancara (Walujo, 1998).

Wawancara bersifat semi struktural yang berpedoman pada daftar pertanyaan (kuisioner sederhana) sebagai pengontrol bagi peneliti untuk mengajukan pertanyaan kepada nara sumber. Untuk wawancara dipilih nara sumber yang dianggap memiliki banyak pengetahuan dan berpengalaman tentang pengobatan tradisional antara lain: Tabib atau orang yang sering melakukan pengobatan tradisional, Tokoh masyarakat, Tokoh adat, dan ditambah beberapa masyarakat yang sering menggunakan tumbuhan sebagai obat-obatan. Identifikasi tumbuhan obat dilakukan di herbarium Manokwari.

\section{Prosedur Kerja}

1. Melakukan survey lokasi dan kondisi area penelitian.

2. Mempersiapkan alat dan bahan.

3. Melakukan wawancara dari informan mengenai jenis dan bagian tumbuhan yang digunakan untuk mengobati penyakit, kegunaan dan nama lokal. Data lain yang dikumpulkan berupa informasi jenis tumbuhan obat yang umum dikenal dan dimanfaatkan masyarakat Marind.

4. Pengambilan sampel tumbuhan berdasarkan hasil wawancara yang dilakukan pada beberapa informan yang dipilih dan masyarakat lain yang bermukim di daerah tersebut.

5. Sampel jenis tumbuhan obat didokumetasikan untuk jenis tumbuhan yang sudah umum ditemui, sedangkan jenis tumbuhan berpotensi didokumentasikan dan dibuat herbarium.

Identifikasi sampel (herbarium) dengan cara memberikan nama ilmiah menurut Kode Internasional Tatanama Tumbuhan (KITT) dengan menggunakan buku acuan Stennis (1992), Tjitrosoepomo (1991) Sastrapradja \& Afriastini, (1980), Henty \& Pritchard (1973) dan Van Balgooy (1998) serta berdasarkan spesimen di Herbarium Manokwariense, Manokwari.

\section{HASIL DAN PEMBAHASAN}

\section{Jenis-Jenis Tumbuhan Berkhasiat Obat}

Penelitian yang dilakukan pada tujuh kampung (Nasem; Kuler; Onggaya; Wasur; Yanggandur; Rawa Biru; Sota) di kawasan Taman Nasional Wasur Kabupaten Merauke ditemukan 46 jenis tumbuhan obat dari 29 famili. Empat puluh enam jenis tumbuhan tersebut memiliki nama lokal (Vernacular name). Jenis tumbuhan obat yang digunakan oleh masyarakat Marind dalam mengobati penyakit beraneka ragam termasuk bagian-bagian yang digunakan. Ada beberapa jenis tumbuhan yang hampir semua kampung menggunakannya namun manfaat dan bagian yang mereka gunakan ada yang berbedabeda.

Tumbuhan yang umum digunakan sebagai obat oleh masyarakat Marind di kawasan Taman Nasional Wasur adalah (Andrographis pamuculata Ness.), (Alstonia scholaris L.), (Cassia alata (Lamk.) Pers.), (Carica papaya L.), (Moringa oleifera Lamk,), (Musa paradisiacal L.) dan (Morinda citrifolia Rump.), namun bagian tumbuhan dan manfaatnya ada yang berbeda-beda, seperti pada pemanfaatan kayu susu (Alstonia scholaris L.) masyarakat Nasem dan Kuler menggunakan kulit dan daun tumbuhan tersebut untuk mengobati penyakit malaria, cacingan dan untuk menambah air susu pada ibu yang sedang menyusui Masyarakat Onggaya, Wasur, Rawa biru, Yanggandur dan Sota daun kayu susu digunakan untuk mengobati sakit gigi dan mengobati luka.

Masyarakat Nasem, Kuler dan Onggaya menggunakan getah pisang untuk menambah 
darah, mengobati sakit gigi, mengobati luka dan mengobati telinga bernanah sedangkan masyarakat Rawa Biru, Yanggandur dan Sota menggunakan daunnya untuk mengobati pegal linu. Tumbuhan mengkudu pada umumnya masyarakat Nasem, Kuler, Wasur dan Onggaya menggunakan daunnya untuk mengobati sakit dalam misalnya paru-paru basah, batuk berdahak, untuk menghilangkan pegal-pegal pada tubuh dan untuk mengobati sakit perut, tetapi masyarakat Rawa Biru, Yanggandur dan Sota menggunakan buahnya untuk menambah stamina (Tabel 1).

\section{Bagian Tumbuhan Yang Dimanfaatkan Sebagai Obat}

Berdasarkan hasil wawancara, ditemukan 46 jenis tumbuhan yang digunakan untuk pengobatan penyakit. Dalam pengobatan, ada beberapa jenis tumbuhan yang hanya dapat diramu oleh orang-orang tertentu saja (Dukun laki-laki $=$ swanggi) misalnya tanaman wati (Piper methysticum Fors.). Ada juga yang langsung dibuat oleh masyarakat biasa atau siapa saja. Masyarakat Marind di Kawasan Taman Nasional Wasur dalam pemanfaatan tumbuhan sebagai obat menggunakan bagian-bagian tertentu saja (Tabel 2).

Hasil pada tabel 2 dapat diketahui bahwa bagian tumbuhan yang paling sering digunakan dalam pengobatan yaitu daun (47.83\%), kemudian lebih dari satu bagian $(21,74 \%)$ lalu disusul oleh kulit $(10,87 \%)$, umbi $(6,52 \%)$, batang $(3,35 \%)$, serta akar, buah, tepung dan getah masing-masing $(2,12 \%)$. Daun sering digunakan dalam pengobatan karena lebih mudah di dapat dan proses pengolahannya pun lebih mudah. Daun merupakan bagian tumbuhan yang hampir selalu

Tabel 1. Jenis-jenis tanaman obat yang dimanfaatkan oleh Masyarakat Marind, di Distrik Merauke Kabupaten Merauke, Papua

\begin{tabular}{|c|c|c|c|c|c|}
\hline No & Famili & Spesies & $\begin{array}{c}\text { Nama Indonesia/ } \\
\text { Lokal }\end{array}$ & $\begin{array}{c}\text { Bagian Yang } \\
\text { Digunakan }\end{array}$ & Manfaat \\
\hline 1 & Acanthaceae & $\begin{array}{l}\text { Andrographis panuculata } \\
\text { Ness. }\end{array}$ & Sambiroto & Daun & - Mengobati malaria \\
\hline 2 & Anacardiaceae & Mangifera indica L. & $\begin{array}{l}\text { Mangga Air } \\
\text { / piaw }\end{array}$ & Kulit & $\begin{array}{l}\text { o Membersihkan saluran } \\
\text { - pencernaan }\end{array}$ \\
\hline 3 & Annonaceae & Annona muricata L. & Sirsak & Daun, & $\begin{array}{l}\text { - Mengobati diare } \\
\text { - Mengobati sakit mata } \\
\text { (mata merah) }\end{array}$ \\
\hline \multirow[t]{2}{*}{4} & Apocynaceae & Alstonia scholaris L. & $\begin{array}{l}\text { Kayu susu } \\
\text { /Sandi,bea }\end{array}$ & Kulit, daun & $\begin{array}{l}\text { - Mengobati sakit malaria, } \\
\text { cacingan, menambah air } \\
\text { susu ibu, mengobati sakit } \\
\text { gigi } \\
\text { - Mengobati luka }\end{array}$ \\
\hline & & $\begin{array}{l}\text { Arthocarpus somusus } \\
\text { (Park.) Fosberg. }\end{array}$ & Sukun/ Balau & $\begin{array}{l}\text { Daun dan } \\
\text { buah }\end{array}$ & $\begin{array}{l}\text { - Mengeringkan tali pusar } \\
\text { pada bayi }\end{array}$ \\
\hline 5 & Apiaceae & Centella asiatica (L.) Urban. & Kaki kuda & Akar & - Menawarkan bisa ular \\
\hline 6 & Arecaceae & $\begin{array}{l}\text { Cocos nucifera L. } \\
\text { Metroxylon sago (Willd.) } \\
\text { Rottb. }\end{array}$ & $\begin{array}{l}\text { Kelapa / Tepiru } \\
\text { Sagu/ Keker }\end{array}$ & $\begin{array}{l}\text { Buah } \\
\text { Tepung }\end{array}$ & $\begin{array}{l}\text { - Mengobati diare } \\
\text { - Mengobati sakit perut } \\
\text { (mual-mual dan diare) }\end{array}$ \\
\hline 7 & Bambucaceae & Bambusa sp & $\begin{array}{l}\text { Bambu / Illa, } \\
\text { Yella }\end{array}$ & Batang & $\begin{array}{l}\text { - Menghentikan darah } \\
\text { - Mempercepat kering pada } \\
\text { luka }\end{array}$ \\
\hline 8 & Caricaceae & Carica papaya L. & $\begin{array}{l}\text { Pepaya/ } \\
\text { Mambepar }\end{array}$ & Akar, daun, & - Mengobati malaria \\
\hline 9 & Cucurbitaceae & Momordica charantia L. & Papare & Daun & $\begin{array}{l}\text { - Menghilangkan lendir pada } \\
\text { tenggorokan }\end{array}$ \\
\hline 10 & Combretaceae & Terminalia catappa L. & $\begin{array}{l}\text { Ketapang/ } \\
\text { Yaryan }\end{array}$ & Kulit & $\begin{array}{l}\text { - Mengobati sakit gigi dan } \\
\text { sakit perut }\end{array}$ \\
\hline
\end{tabular}


Tabel 1. Lanjutan ..........

\begin{tabular}{|c|c|c|c|c|c|}
\hline No & Famili & Spesies & $\begin{array}{c}\text { Nama Indonesia/ } \\
\text { Lokal }\end{array}$ & $\begin{array}{l}\text { Bagian Yang } \\
\text { Digunakan }\end{array}$ & Manfaat \\
\hline 11. & Convolvulaceae & Ipomoea triloba $\mathrm{L}$. & Kumkari & Daun & $\begin{array}{l}\text { - Mengobati diare dan muntah } \\
\text {-muntah }\end{array}$ \\
\hline \multirow[t]{3}{*}{12.} & Euphorbiaceae & Phyllanthus niruri L. & Meniran & $\begin{array}{l}\text { Akar, batang, } \\
\text { daun }\end{array}$ & $\begin{array}{l}\text { - Memperlancar proses } \\
\text { kelahiran }\end{array}$ \\
\hline & & Ricinus communis L. & Jarak / Ndamas & Getah & $\begin{array}{l}\text { - Menghilangkan luka di sela- } \\
\text { sela bibir }\end{array}$ \\
\hline & & $\begin{array}{l}\text { Manihot utilisima } \\
\text { Crantz. }\end{array}$ & Ubi kayu & Daun & - Membersihkan mata \\
\hline \multirow[t]{6}{*}{13.} & Fabaceae & Bauhinia sp & Kuiu & Daun & - Menghilangkan mual-mual \\
\hline & & $\begin{array}{l}\text { Cassia alata (Lamk.) } \\
\text { Pers. }\end{array}$ & Ketepeng & Daun & - Mengobati kudis dan panu \\
\hline & & $\begin{array}{l}\text { Kingiodendron } \\
\text { platycarpum Bent. }\end{array}$ & Baingga & Daun & $\begin{array}{l}\text { - Mengobati haid yang tidak } \\
\text { teratur } \\
\text { - Mengeluarkan darah mati } \\
\text { - Mengobati luka dalam }\end{array}$ \\
\hline & & $\begin{array}{l}\text { Peltophorum } \\
\text { pterocarpum Back. }\end{array}$ & $\begin{array}{l}\text { Kayu } \\
\text { timur/Njamor, } \\
\text { Pingkui, }\end{array}$ & Kulit, daun & - Mengobati sakit perut/diare \\
\hline & & Intsia bijuga A. Gray. & $\begin{array}{l}\text { Kayu besi/ } \\
\text { Kanda }\end{array}$ & Kulit & $\begin{array}{l}\text { - Membersihkan sisa kotoran } \\
\text { setelah melahirkan }\end{array}$ \\
\hline & & Sophora tomentosa L. & $\begin{array}{l}\text { Asam hutan/ } \\
\text { Talombo, } \\
\text { Ndembum }\end{array}$ & Daun & $\begin{array}{l}\text { - Mengobati batuk dan paru- } \\
\text { paru basah } \\
\text { - Menurunkan panas/demam }\end{array}$ \\
\hline 14. & Gesneriaceae & Cyrtandra sp & Wati-wati & Daun & $\begin{array}{l}\text { - Menghilangkan pegal-pegal } \\
\text { pada tubuh }\end{array}$ \\
\hline \multirow[t]{2}{*}{15.} & Lamiaceae & $\begin{array}{l}\text { Orthosiphon spiantus } \\
\text { B.B.J. }\end{array}$ & Kumis kucing & Daun & $\begin{array}{l}\text { - Mempermudah saat } \\
\text { melahirkan }\end{array}$ \\
\hline & & Coleus blumei Benth. & Mayana & Daun & - Menambah darah \\
\hline 16. & Loranthaceae & $\begin{array}{l}\text { Dendrophthoe pendantra } \\
\text { Benth. }\end{array}$ & Benalu/ Malob & Akar, batang & $\begin{array}{l}\text { - Membersihkan sisa kotoran } \\
\text { setelah haid }\end{array}$ \\
\hline 17. & Malvaceae & Hibiscus tiliaseus L. & Waru /Wakati, & Kulit, daun & - Menambah darah \\
\hline 18. & Menispermaceae & Tinopspora disstiflora $\mathrm{L}$. & Tali-tali & Batang & - Mengobati malaria \\
\hline 19. & Moringaceae & Moringa oleifera Lamk. & Kelor & Daun, & $\begin{array}{l}\text { - Menambah nafsu maka, } \\
\text { - menambah air susu ibu } \\
\text { - Mengobati paru-paru basah, } \\
\text { - malaria, menambah darah, } \\
\text { - Mengobati panu } \\
\text { - Menghilangkan pegal-pegal } \\
\text { setelah melahirkan }\end{array}$ \\
\hline 20. & Musaceae & Musa paradisiaca $\mathrm{L}$. & Pisang/ Dewaka & Getah, daun & $\begin{array}{l}\text { - Menambah darah } \\
\text { - Mengobati sakit gigi, telinga } \\
\text { nanah } \\
\text { - Menghilangkan pegel linu } \\
\text { - Mengobati luka }\end{array}$ \\
\hline \multirow[t]{3}{*}{21.} & Myrtaceae & $\begin{array}{l}\text { Eugenia aguwea (L.) } \\
\text { Kulz. }\end{array}$ & $\begin{array}{l}\text { Jambu merah } \\
\text { /Hubiara }\end{array}$ & Kulit, & $\begin{array}{l}\text { - Mengobati bisul dalam perut } \\
\text { - Mengobati batuk kering }\end{array}$ \\
\hline & & $\begin{array}{l}\text { Melaleuca } \\
\text { leucandendron L. }\end{array}$ & Kayu putih & Daun & $\begin{array}{l}\text { - Menghilangkan mual-mual } \\
\text { dan Masuk angin }\end{array}$ \\
\hline & & Psidium guajava L. & Jambu biji & Daun & - Mengobati diare \\
\hline \multirow[t]{2}{*}{22.} & Piperaceae & Piper betle L. & Sirih & Daun & - Membersihkan mata \\
\hline & & $\begin{array}{l}\text { Piper methysticum } \\
\text { Forst. }\end{array}$ & Wati & Daun & $\begin{array}{l}\text { - Membersihkan paru-paru. } \\
\text { - Membersihkan saluran } \\
\text { pencernaan }\end{array}$ \\
\hline
\end{tabular}


Tabel 1. Lanjutan ...........

\begin{tabular}{|c|c|c|c|c|c|}
\hline No & Famili & Spesies & $\begin{array}{l}\text { Nama Indonesia/ } \\
\text { Lokal }\end{array}$ & $\begin{array}{c}\text { Bagian Yang } \\
\text { Digunakan }\end{array}$ & - Manfaat \\
\hline 23. & Pittosporaceae & Pittosporum sp & Pajor & Daun & - Mengobati diare \\
\hline \multirow[t]{2}{*}{24.} & Poaceae & Andropogon nardus L. & Serai/ Luf & $\begin{array}{l}\text { Akar, batang } \\
\text { daun }\end{array}$ & $\begin{array}{l}\text { - Menghilangkan rasa pegal- } \\
\text { pegal setelah melahirkan, } \\
\text { - Mengobati patah tulang } \\
\text { - Membersihkan mata akibat } \\
\text { lendir, mengobati luka dalam }\end{array}$ \\
\hline & & Imperata cylindrica Var. & $\begin{array}{l}\text { Alang-alang } \\
\text { /Kumasa, Wes }\end{array}$ & Daun & - Mengobati luka \\
\hline \multirow[t]{2}{*}{25.} & Rubiaceae & $\begin{array}{l}\text { Morinda citrifolia } \\
\text { Rump. }\end{array}$ & $\begin{array}{l}\text { Mengkudu/ } \\
\text { Gidu, wambikan }\end{array}$ & Daun, buah & $\begin{array}{l}\text { - Mengobati sakit dalam } \\
\text { - Menghilangkan pegal-pegal } \\
\text { pada badan, sakit perut } \\
\text { - Menambah stamina }\end{array}$ \\
\hline & & Nauclea orintalis L. & Gempol /Gal & Kulit & $\begin{array}{l}\text { - Menambah darah } \\
\text { - Menghilangkan lendir pada } \\
\text { saluran pernafasan }\end{array}$ \\
\hline 26. & Rutaceae & $\begin{array}{l}\text { Citrus aurantifolia } \\
\text { Swingle. }\end{array}$ & Jeruk & Daun & - Mengobati sakit gigi \\
\hline 27. & Solanaceae & Capsicum fructescens $\mathrm{L}$. & Lombok & Daun & $\begin{array}{l}\text { - Mengobari luka agar cepat } \\
\text { kering }\end{array}$ \\
\hline 28. & Urticaceae & $\begin{array}{l}\text { Laportea interupta (L.) } \\
\text { Chew. }\end{array}$ & Daun gatal & Daun & $\begin{array}{l}\text { - Menghilangkan pegal-pegal } \\
\text { pada badan } \\
\text { - Mengobati kaskadu }\end{array}$ \\
\hline \multirow[t]{3}{*}{29.} & Zingiberaceae & Curcuma domestica Val. & Kunyit / Mbreu & Umbi & $\begin{array}{l}\text { - Mengobati luka yang susah } \\
\text { kering }\end{array}$ \\
\hline & & Languas galanga Val. & Lengkuas & Umbi & - Mengobati panu \\
\hline & & $\begin{array}{l}\text { Zingiber officinalis } \\
\text { Rosc. }\end{array}$ & Jahe & Umbi & $\begin{array}{l}\text { - Mengobati mual-mual dan } \\
\text { batuk berhadak }\end{array}$ \\
\hline
\end{tabular}

digunakan dengan cara dicampur (diramu) dengan jenis bahan lain.

Selain daun, bagian kulit dan batang juga mempunyai persentase yang cukup besar dari bagian tumbuhan yang dimanfaatkan.

Tabel 2. Persentase pemanfaatan bagian organ tumbuhan sebagai bahan obat.

\begin{tabular}{llcc}
\hline No & $\begin{array}{c}\text { Bagian Yang } \\
\text { Digunakan }\end{array}$ & Jumlah & Persentase \\
\hline 1 & Daun & 22 & 47.83 \\
2 & Kulit & 5 & 10.87 \\
3 & Akar & 1 & 2.17 \\
4 & Buah & 1 & 2.17 \\
5 & Batang & 2 & 3.35 \\
6 & Tepung & 1 & 2.17 \\
7 & Getah & 1 & 2.17 \\
8 & Umbi & 3 & 6.52 \\
9 & Lebih dari satu & 10 & 21.74 \\
& bagian & & \\
\hline & Jumlah & 46 & 100 \\
\hline
\end{tabular}

\section{KESIMPULAN}

\section{Kesimpulan}

Berdasarkan hasil observasi yang telah dilakukan maka dapat disimpulkan sebagai berikut:

1. Jenis tanaman obat yang digunakan oleh masyarakat Marind berjumlah 46 jenis dari 29 famili dengan habitat yang berbeda-beda, diantaranya hutan, kebun, pinggir jalan dan pekarangan rumah. Pinggiran hutan merupakan habitat utama dari sebagian besar jenis tumbuhan obat yang ditemukan.

2. Pemanfaatan tumbuhan obat beraneka ragam, tetapi pada umumnya digunakan untuk mengobati jenis penyakit yang sering diderita misalnya sakit dalam atau sakit luar. Jenis sakit luar diantaranya luka potong, sakit gigi, sakit kulit dan lain-lain. Sakit dalam misalnya 
mengobati sakit perut, demam, diare, paruparu basah, batuk dan lain-lain.

3. Dari 46 jenis tanaman obat ditemukan 7 jenis tanaman berpotensi untuk dikembangkan atau diteliti lebih lanjut yaitu; tumbuhan Kuiu (Bauhinia sp), Pajor (Pittosporum sp), Baingga (Kingiodendron platycarpum Bent.) Talombo (Sophora tomentosa L.) Wati-wati (Cyrtandra $\mathrm{sp})$, Kumkari (Ipomoea triloba L.), Tali-tali (Tinopspora disstiflora L.).

\section{Saran}

1. Perlu adanya perhatian pemerintah setempat terkhusus dalam pembudidayaan jenis-jenis tanaman obat tradisional, sebagai upaya pelestarian warisan pengetahuan nenek moyang orang Papua.

2. Perlu adanya penelitian lebih lanjut tentang tanaman obat khususnya pada daerah-daerah terpencil di Papua guna menambah keanekaragaman pengetahuan masyarakat Indonesia pada umumnya.

3. Perlu adanya penelitian lanjutan dari penelitian ini, khususnya dibidang farmakologi untuk menggali potensi dari obat tradisional dan mencari sumber-sumber obat baru dari kekayaan alam tumbuhan kita.

\section{DAFTAR PUSTAKA}

Badan Pusat Statistik. 2002. Laporan Tahunan: Merauke Dalam Angka. BPS Kabupaten Merauke.

Dinas Kehutanan dan Perkebunan. Dirjen Perlindungan dan Konservasi lam Balai Taman Nasional Wasur. 1999. Rencana Pengelolaan Taman Nasional Wasur 1999-2024. WWF, Merauke.

Henty, E.E., dan G.H. Pritchard. 1973. Division of Botany. Department of Forest Lae. Papua New Guinea.

Hernani dan C. Syukur. 2002. Budidaya Tanaman Obat Komersial. PT. Penebar Swadaya. Jakarta.

Rahardi, F. 1996. Membuat Kebun Tanaman Obat. Puspa Suara, Jakarta.

Rully, A. 2001. Pemanfaatan Tumbuhan Obat pada Masyarakat Suku Iha di Desa Danaweri Kabupaten Fak-fak. Skripsi. Universitas Cenderawasih, Jayapura.

Sastrapradja, S., dan J.J. Afriastini. 1980. Jenis Rumput Dataran Rendah. Lembaga Biologi Nasional LIPI. Bogor.

Stennis, V.C.G.G.J. 1992. Flora Untuk Sekolah di Indonesia. PT. Pradnya Paramita. Jakarta.

Tjitrosoepomo, G. 1991. Taksonomi Tumbuhan (Spermatophyta). Gadjah Mada University Press. Yogyakarta.

Van Balgooy, M.M.J. 1998. Melanesia Seed Plants. Rijksherbarium Hartus Batinicus. Leiden.

Walujo, E.B. 1998. Etnobotani, Metode Penelitian Baru Penggabungan Antara Konsep Ilmu-llmu Sosial dan Ilmu Biologi. Prosiding Seminar Nasional Etnobotani III. 5 - 6 Mei 1998. 

Halaman: 65-71

\title{
Kualitas Sumber Air Minum Masyarakat Kampung Yokiwa Distrik Sentani Timur Secara Bakteriologis
}

\author{
IMA FITHA PATASIK DAN DANIEL LANTANG* \\ Jurusan Biologi FMIPA Universitas Cenderawasih, Jayapura-Papua \\ Diterima: tanggal 28 Mei 2009 - Disetujui: 31 Juli 2009 \\ (C) 2009 Jurusan Biologi FMIPA Universitas Cenderawasih
}

\begin{abstract}
The aim of this study was to observe the presence of coliform bacteria and the level of contamination in outlet water of Sentani lake, especially in Jaifuri river. The study was done from Januari-April 2009 in 3 sampling areas: outlet of the lake (A), in between outlet and the river (B), and in Jaifuri river (C). Samples then be analized in Biology Laboratory, FMIPA University of Cenderawasih using MPN (Most Probable Number) series 3-3-3. Furthermore, the result then compared with the quality standard of dringking water (Peraturan Menteri Kesehatan RI No 416/MENKES/PER/IX1990). The result showed that coliform of sample A was $9.300 \mathrm{MPN} / 100 \mathrm{ml}$, sample B was $4.300 \mathrm{MPN} / 100 \mathrm{ml}$ and sample C was $24.000 \mathrm{MPN} / 100 \mathrm{ml}$. That condition was above the maximum level of contamination of dringking water $(0 / 100 \mathrm{ml})$. In addition, the biochemical test showed that Escherichia coli and Klebsiella pneumoniae were found in that water samples.
\end{abstract}

Key words: Coliform, Escherichia coli, outlet of Sentani lake, Jaifuri river, East Sentani.

\section{PENDAHULUAN}

Perairan permukaan seperti danau, sungai, muara dan lautan merupakan suatu ekosistem yang amat kompleks. Perairan demikian lebih rentan terhadap pencemaran berkala oleh mikroorganisme dari air atmosfer serta akibat pembuangan limbah domestik dan non domestik ke aliran air pada permukaan tanah. Terdapat perbedaan populasi mikroba pada perairan permukaan yang disebabkan karena perbedaan ketersediaan kandungan nutrien bagi mikroba, keadaan fisik, dan ciri-ciri biologinya (Irianto, 2006). Menurut Suriawiria (1995), perairan alami merupakan habitat atau tempat yang sangat parah

\footnotetext{
*Alamat Korespondensi: Jurusan Biologi FMIPA, Jln. Kamp Wolker, Kampus Baru UNCEN-WAENA, Jayapura Papua. 99358, Telp. (0967) 572115. email: d_lantang@yahoo.co.id
}

terkena pencemaran. Air yang mempunyai rumus kimia air $\mathrm{H}_{2} \mathrm{O}$ berfungsi sebagai air bersih seperti akuades, akuademin dan sebagainya. Sedangkan untuk air alami yang berada di dalam sungai, kolam, danau, laut dan sumber-sumber lainnya akan menjadi: $\mathrm{H}_{2} \mathrm{O}$ ditambah dengan faktor yang bersifat biotik dan abiotik. Faktor biotik dalam perairan seperti bakteria, fungi, mikroalga, protozoa, virus serta kumpulan hewan atau tumbuhan air lainnya yang tidak termasuk kelompok mikroba.

Sungai-sungai membawa lebih banyak atau lebih sedikit limbah yang membawa bakteri tergantung limpahan limbah yang terbuang. Sebagai contoh adalah bakteri intestinal Escherichia coli yang dinamakan strain koliform dan Salmonella patogenik sebagai penyebab demam tifoid.

Volk \& Wheeler (1990) mengungkapkan bahwa air layak minum adalah air yang bebas dari substansi berbahaya dan memiliki penampilan 
atau rasa yang dikehendaki. Sedangkan air dikatakan terkontaminasi apabila air mengandung bahan kimia yang beracun atau organisme patogen (secara mikrobiologi) tetapi masih jernih. Air minum yang mengandung mikroorganisme patogen dapat menyebabkan penyakit pada manusia. Kehadiran bakteri Coliform dapat membuktikan kualitas air minum secara bakteriologis yaitu apabila tidak ada bakteri Coliform per $100 \mathrm{ml}$ maka kualitas air sangat memuaskan.

Danau Sentani terletak di Jayapura Papua yaitu di antara pegunungan Cyclops dengan letak geografis $2^{\circ} 23-2^{\circ} 41$ LS dan $140^{\circ} 38^{\prime}-140^{\circ} 38$ BT yang terdiri dari 24 perkampungan yang tersebar di pesisir dan pulau-pulau kecil yang berada di tengah danau. Sumber air danau Sentani berasal dari 14 sungai besar maupun kecil yang ada di Jayapura dan hanya memiliki 1 muara (outlet) yaitu pada daerah Puay. Puay secara geografis terletak pada $02^{\circ} 41^{\prime \prime} 23,7$ LS dan $140^{\circ} 34^{\prime \prime} 34,4$ BT yang terdiri dari 1 sungai yaitu Jaifuri yang merupakan daerah aliran dari air keluaran (outlet) Danau Sentani yang kemudian bergabung dengan sungai Tami dan akhirnya bermuara di Samudera Pasifik (Lukman \& Fauzi, 1991; Badjoeri \& Lukman, 2007).

Beberapa kampung berada pada tepi outlet danau Sentani yaitu Kampung Puay dan kampung Yokiwa Distrik Sentani Timur. Masyarakat yang bermukim di kampung Yokiwa memanfaatkan air sungai Jaifuri secara langsung sebagai akibat dari tidak adanya sumber air bersih. Berdasarkan permasalahan tersebut maka perlu dilakukan penelitian secara mikrobiologi yaitu dengan menganalisis kadar kontaminasi Coliform dan pengujian secara biokimia bakteri Escherichia coli pada outlet Danau Sentani di Distrik Sentani Timur, Jayapura.

\section{METODE PENELITIAN}

\section{Lokasi dan Waktu Penelitian}

Penelitian ini dilaksanakan di Laboratorium Biologi FMIPA Uncen Waena dengan memeriksa sampel air yang diambil dari air keluaran (outlet) Sungai Jaifuri, Danau Sentani Distrik Sentani
Timur yang berlangsung pada bulan Januari 2009April 2009.

\section{Alat dan Bahan}

Alat yang digunakan dalam penelitian ini antara lain adalah botol sampel $( \pm 100 \mathrm{ml}$, berwarna gelap), $\mathrm{pH}$ meter, thermometer, cool box, cessi disk, autoklaf, inkubator, laminar air flow, mikroskop, timbangan analitik, hot plate, rak tabung reaksi, tabung reaksi, tabung durham, gelas beker, tabung erlenmeyer, cawan petri, pipet volumetrik, pipet tetes, batang pengaduk, jarum ose, lampu spiritus, loupe, kaca objek dan kamera digital. Sampel air keluaran (outlet) danau Sentani, alkohol 70\%, alumunium foil.

Media yang digunakan adalah Lactose Broth (LB), Eosyn Methylene Blue (EMB), Brilliant Green Lactose Bile (BGLB), Nutrien Agar (NA), Media gula-gula (Glukosa, Laktosa, Manitol, Maltosa, Sukrosa), SIM (Sulfid Indol Mutility), Simmon's Citrat Agar, MR-VP (Methyl Red- Voges Proskauer), Methyl Red, VP1 dan VP2, dan Larutan kovacs.

\section{Metode Penelitian}

Metode yang digunakan adalah Metode Observasi, metode ini digunakan untuk mengetahui kondisi lokasi penelitian dan menentukan daerah aliran sebagai titik pengambilan sampel., Metode MPN (Most Probable Number), metode MPN ini menggunakan sistem 33-3 untuk menguji perkiraan/ pendugaan kadar kontaminasi Coliform. Kemudian dilanjutkan dengan uji penguat dan pelengkap.

\section{Prosedur Penelitian}

1. Menentukan titik dan pengambilan sampel pada air keluaran (outlet) danau Sentani yaitu titik A (Puay I), yang dekat dengan muara danau sentani; titik B sebelum sungai Jaifuri, dan titik $C$ di sungai Jaifuri, $\pm 7 \mathrm{~m}$ menjauh dari kampung Yokiwa. Untuk setiap titik dilakukan tiga replikasi sehingga jumlah seluruh sampel adalah 9 sampel.

2. Uji kandungan Coliform, dengan pengenceran sampel 10-1, 10-2 dan $10^{-3}$. 
Tahapan analisis kadar kontaminasi Coliform teridir dari uji penduga, penegas, dan uji pelengkap.

a. Uji penduga (presumptive test), yaitu mengamati perubahan reaksi yang positif dan mengkonfirmasikan hasil perhitungan dengan tabel MPN untuk mengetahui jumlah kandungan Coliform dalam $100 \mathrm{ml}$ sampel air. Media yang digunakan adalah LB dalam tiga tingkatan pengenceran.

b. Uji penegas (confirmed test), menginokulasi biakan dari tabung LB yang positif ke media $\mathrm{EMB}$, diinkubasi pada suhu $37^{\circ} \mathrm{C}$ selama 24 jam. Pertumbuhan koloni ditandai warna hijau dengan kilap logam dan bintik biru kehijauan sampai kehitaman yang menunjukan adanya bakteri Coli. Menyiapkan media BGLB sesuai dengan jumlah koloni yang positif tumbuh pada media EMB. Selanjutnya memindahkan koloni menggunakan jarum ose, dan diinkubasikan pada suhu $37^{\circ} \mathrm{C}$ selama 24 jam. Tabung positif ditandai dengan kekeruhan dan gas di dalam tabung durham.

c. Uji pelengkap (completed test), menginokulasi koloni yang berwarna hijau metalik dari media EMB ke dalam media NA (natrium agar) miring, dan melakukan pengecatan gram dari biakan yang di kultur pada media EMB.

\section{Uji biokimia}

a. Menginokulasi koloni berwarna hijau metalik dari media EMB ke masing-masing media gula-gula (Glukosa, Laktosa, Manitol, Maltosa, Sukrosa). Hasil positif apabila terjadi perubahan warna merah menjadi kuning pada semua media gulagula tersebut dan terbentuknya gas di tabung durham pada media glukosa.

b. SIM (Sulfid Indol Mutility), dari media EMB diinokulasikan ke media SIM, inkubasi pada suhu $37^{\circ} \mathrm{C}$ selama 24 jam. Untuk melihat Indol maka ditetesi dengan pelarut kovacs. Hasil positif Indol apabila terbentuk cincin merah pada bagian atas, adanya penyebaran yang berwarna putih, timbulnya warna hitam pada media menunjukkan adanya $\mathrm{H}_{2} \mathrm{~S}$ yang dihasilkan.

c. Simmon's Citrat Agar, menginokulasikan biakan dari EMB, lalu membiakan pada media Simmon's Citrat secara zigzag pada permukaannya, suhu $37^{\circ} \mathrm{C}$ selama 24 jam. Hasil positif jika terjadi perubahan warna hijau menjadi biru.

d. MR-VP (Methyl Red- Voges Proskauer), dari EMB menanamnya pada media MRVP yang telah dibagi menjadi 2 bagian yaitu untuk uji MR dan uji VP.

1. Uji MR (Methyl Red), hasil positif jika terjadi terjadi perubahan menjadi merah.

2. Uji VP (Voges Proskauer), perubahan warna yang terjadi dalam 2-4 jam. Hasil positif apabila terjadi perubahan warna media menjadi merah (Ramadhany \& Amiruddin, 2008).

\section{Analisis Data}

Data yang diperoleh dari hasil pengamatan kemudian dikonversikan ke dalam tabel MPN lalu disesuaikan dengan peraturan PERMENKES RI No.146/MENKES/1990 tentang standar kualitas air minum dan juga dianalisis sesuai dengan pengujian secara biokimia.

$$
\begin{aligned}
& \text { MPN sampel } \\
& =\text { Nilai MPN Tabel } X \frac{1}{\text { pengenceran tabung tengah }}
\end{aligned}
$$

\section{HASIL DAN PEMBAHASAN}

\section{Jumlah Coliform pada Air Keluaran (Outlet) Danau Sentani}

Hasil pengujian 3 (tiga) sampel air yang dilakukan pada uji penduga dengan media LB (Lactose Broth) menunjukkan adanya bakteri Coliform pada air keluaran (Outlet) danau Sentani. Hal tersebut ditandai dengan timbulnya gas pada tabung durham dan terjadi perubahan warna media menjadi keruh. 
Tabel 1. Jumlah Coliform/ $100 \mathrm{ml}$ sampel air pada 3 (tiga) titik pengambilan sampel di keluaran (Outlet) danau Sentani yang diuji menggunakan media LB (Lactose Broth).

\begin{tabular}{|c|c|c|c|c|c|}
\hline \multirow[t]{2}{*}{ Sampel } & \multicolumn{3}{|c|}{$\begin{array}{l}\sum \text { tabung positif } \\
\text { (pengenceran) }\end{array}$} & \multirow[t]{2}{*}{$\begin{array}{l}\text { Nilai } \\
\text { MPN }\end{array}$} & \multirow{2}{*}{$\begin{array}{c}\text { Jumlah } \\
\text { Coliform/ } \\
100 \mathrm{ml}\end{array}$} \\
\hline & $10^{-1}$ & $10^{-2}$ & $10^{-3}$ & & \\
\hline A & 3 & 3 & 1 & 460 & 46.000 \\
\hline B & 3 & 2 & 1 & 150 & 15.000 \\
\hline C & 3 & 3 & 1 & 460 & 46.000 \\
\hline
\end{tabular}

Nilai MPN (Tabel 1) yang diperoleh pada 3 (tiga) titik pengambilan sampel tersebut, dapat dilihat bahwa daerah muara Danau Sentani (sampel A) dan daerah aliran Sungai Jaifuri (sampel C) memiliki jumlah Coliform yang sama yaitu $46.000 \mathrm{MPN} / 100 \mathrm{ml}$ sampel air, sedangkan pada sampel B yang berada diantara daerah muara danau sentani dan sungai Jaifuri memiliki jumlah Coliform yang lebih rendah yaitu 15.000 MPN/ $100 \mathrm{ml}$ sampel air. Hasil nilai MPN yang diperoleh dari 3 titik pengambilan sampel pada air keluaran (outlet) Danau Sentani tersebut menunjukkan bahwa air keluaran (outlet) Danau Sentani memiliki kadar jumlah Coliform yang melebihi batas kadar maksimum yang diperbolehkan untuk syarat air minum yaitu 0 / $100 \mathrm{ml}$ sampel air.

\section{Penegasan Keberadaan Bakteri Coliform}

Hasil pengamatan pada media EMB menunjukkan hasil positif adanya pertumbuhan koloni bakteri. Koloni bakteri yang tumbuh tersebut merupakan koloni bakteri yang berwarna hijau metalik yaitu hijau dengan kilap logam pada bagian tengahnya dan juga koloni berwarna merah muda.

Hasil pertumbuhan koloni pada media EMB (tabel 2) diketahui bahwa terjadi pertumbuhan koloni bakteri berwarna hijau metalik dan koloni bakteri berwarna merah.

Hasil pengamatan pada media BGLB, hasil positif ditandai dengan perubahan warna media menjadi keruh dan terbentuknya gas pada tabung durham.

Hasil uji dengan media BGLB (Tabel 3), sampel yang memiliki jumlah Coliform/ $100 \mathrm{ml}$ sampel air terbanyak adalah sampel C dengan jumlah 24.000 MPN/ $100 \mathrm{ml}$. Kemudian diikuti dengan sampel A yaitu $9.300 \mathrm{MPN} / 100 \mathrm{ml}$ dan sampel B yaitu $4.300 \mathrm{MPN} / 100 \mathrm{ml}$. Pada tabung BGLB yang positif kemudian diinokulasikan ke media EMB untuk memastikan kembali keberadaan Coliform dalam sampel air.

Tabel 2. Koloni bakteri yang tumbuh pada media EMB yang diinkubasi pada suhu $37^{\circ} \mathrm{C}$ selama 24 jam.

\begin{tabular}{clcc}
\hline Sampel & Pengenceran & \multicolumn{2}{c}{ Koloni bakteri } \\
\cline { 3 - 4 } & & $\begin{array}{c}\text { Hijau } \\
\text { Metalik }\end{array}$ & $\begin{array}{c}\text { Merah } \\
\text { Muda }\end{array}$ \\
\hline A & A 10-1 (I) & - & + \\
& A 10-1 (II) & - & + \\
A 10-3 (III) & - & + \\
A 10-2 (I) & - & + \\
A 10-2 (II) & + & - \\
& A 10-2 (III) & + & - \\
A 10-3 (III) & - & + \\
& B 10-1 (I) & + & + \\
B 10-1 (II) & + & - \\
& B 10-1 (III) & + & + \\
B 10-2 (I) & - & + \\
& B 10-2 (III) & - & + \\
B 10-3 (III) & - & + \\
C 10-1 (I) & + & - \\
C & C 10-1 (II) & - & + \\
& C 10-1 (IV) & + & + \\
C 10-2 (I) & - & + \\
C 10-2 (II) & + & - \\
C 10-2 (III) & + & - \\
C 10-3 (III) & - & + \\
\hline
\end{tabular}

Hasil pengamatan pada tabel 4 menunjukkan bahwa biakan yang dikultur dari tabung BGLB ke media EMB, semua biakan tumbuh sama yaitu koloni berwarna hijau metalik dan koloni berwarna merah muda. Karakteristik koloni hijau metalik yang tumbuh yaitu bentuk koloninya bulat, permukaan koloni rata, dan penyebaran koloninya merata. Pada koloni yang berwarna merah memiliki ciri-ciri yaitu koloninya tidak terhingga, bentuk koloni bulat, permukaan timbul datar dan rata, tepi koloni ombak dan penyebarannya merata. 
Tabel 3. Jumlah Coliform/100 ml sampel air pada 3 (tiga) titik pengambilan sampel di keluaran (Outlet) Danau Sentani yang diuji menggunakan media BGLB.

\begin{tabular}{cccccc}
\hline Sampel & \multicolumn{2}{c}{$\begin{array}{c}\sum \text { tabung positif } \\
\text { (pengenceran) }\end{array}$} & $\begin{array}{c}\text { Nilai } \\
\text { MPN }\end{array}$ & $\begin{array}{c}\text { Jumlah } \\
\text { Coliform } \\
/ 100 \mathrm{ml}\end{array}$ \\
\cline { 2 - 4 } & $10^{-1}$ & $10^{-2}$ & $10^{-3}$ & & 9.300 \\
$\mathrm{~A}$ & 3 & 2 & 0 & 93 & 4.300 \\
$\mathrm{~B}$ & 3 & 1 & 0 & 43 & 24.000 \\
$\mathrm{C}$ & 3 & 3 & 0 & 240 & \\
\hline
\end{tabular}

Koloni bakteri yang tumbuh pada media EMB tersebut selanjutnya dilakukan pewarnaan Gram untuk mengetahui apakah bakteri tersebut Gram+ (positif) atau Gram- (negatif). Bakteri dari koloni bakteri yang berwarna hijau metalik memiliki bentuk batang (bacillus) dan warna bakterinya adalah merah. Bakteri dari koloni yang berwarna merah muda memiliki bentuk bulat (coccus) dengan warna bakteri yaitu merah.

Kedua koloni bakteri tersebut merupakan golongan bakteri Gram - (Negatif). Bakteri Gram (negatif) merupakan bakteri yang memiliki struktur dinding sel yang berlapis dan lebih kompleks dibandingkan bakteri Gram + (positif). Bakteri Gram - (negatif) mampu mengikat safranin karena kandungan peptidoglikan yang tipis pada dinding selnya (Waluyo, 2007).

Pengujian secara biokimia menggunakan media gula-gula, SIM (Sulfid Indol Mutillity), Simmon's Citrat Agar dan MR-VP (Methyl RedVoges Proskauer) menunjukkan bahwa pada koloni berwarna hijau metalik baik pada sampel I maupun sampel II merupakan Escherichia coli. Hal ini dapat dilihat dari hasil uji yang sama pada media gula-gula dengan hasil positif (Tabel 5).

Tabel 4. Koloni bakteri yang tumbuh pada media EMB setelah inkubasi pada suhu $37^{\circ} \mathrm{C}$ selama 24 jam.

\begin{tabular}{clcc}
\hline Sampel & Pengenceran & \multicolumn{2}{c}{ Koloni bakteri } \\
\cline { 3 - 4 } & & $\begin{array}{c}\text { Hijau } \\
\text { Metalik }\end{array}$ & $\begin{array}{c}\text { Merah } \\
\text { Muda }\end{array}$ \\
\hline A & A 10-1 (I) & - & + \\
& A 10-1 (II) & - & + \\
A 10-3 (III) & - & + \\
A 10-2 (I) & - & + \\
A 10-2 (II) & + & - \\
& A 10-2 (III) & - & - \\
A 10-3 (III) & - & - \\
& B 10-1 (I) & + & + \\
B 10-1 (II) & - & + \\
& B 10-1 (III) & - & + \\
B 10-2 (I) & - & + \\
B 10-2 (III) & - & - \\
B 10-3 (III) & - & - \\
C 10-1 (I) & + & - \\
C & C 10-1 (II) & + & + \\
& C 10-1 (III) & + & - \\
C 10-2 (I) & - & + \\
C 10-2 (II) & - & + \\
C 10-2 (III) & - & + \\
C 10-3 (III) & - & - \\
\hline
\end{tabular}

\section{Pengujian Escherichia coli dengan uji biokimia}

Hasil pengujian biokimia dari koloni merah muda menunjukkan ciri-ciri dari bakteri Klebsiella

Tabel 5. Hasil uji biokimia terhadap koloni bakteri dari sampel pengamatan.

\begin{tabular}{|c|c|c|c|c|c|c|c|c|c|c|c|c|}
\hline \multirow[t]{2}{*}{ Koloni } & \multicolumn{5}{|c|}{ Media Gula-gula } & \multicolumn{3}{|c|}{ SIM } & \multirow[t]{2}{*}{ SC } & \multicolumn{2}{|c|}{ MR-VP } & \multirow[t]{2}{*}{ Bakteri teridentifikasi } \\
\hline & G & $\mathrm{L}$ & $\mathrm{Mn}$ & $\mathrm{Ml}$ & S & $\mathrm{H} 2 \mathrm{~S}$ & $\mathrm{I}$ & M & & MR & $\mathrm{VP}$ & \\
\hline HM 1 & + & + & + & + & + & - & + & + & - & + & - & E. coli \\
\hline HM 2 & + & + & + & + & + & - & + & + & - & + & - & E. coli \\
\hline $\mathrm{MM}$ & + & + & + & + & + & - & - & + & + & + & - & Klebsiella pneumoniae \\
\hline \multicolumn{13}{|c|}{ Keterangan: } \\
\hline HM 1 & \multicolumn{5}{|c|}{ : Hijau Metalik sampel 1} & \multicolumn{2}{|l|}{$S$} & \multicolumn{4}{|c|}{ : Sukrosa } & \\
\hline HM 2 & \multicolumn{4}{|c|}{ : Hijau Metalik sampel 2} & & \multicolumn{2}{|l|}{ I } & \multicolumn{4}{|c|}{ Indol } & \\
\hline MM & \multicolumn{4}{|c|}{ : Merah Muda } & & \multicolumn{2}{|l|}{ M } & \multicolumn{4}{|c|}{ : Mutility } & \\
\hline G & \multicolumn{4}{|c|}{ : Glukosa } & & \multicolumn{2}{|l|}{ MR } & \multicolumn{4}{|c|}{ Metyl Red } & \\
\hline $\mathrm{L}$ & \multicolumn{4}{|c|}{ : Laktosa } & & \multicolumn{2}{|l|}{ VP } & \multicolumn{4}{|c|}{ Voges Proskauer } & \\
\hline Mn & \multicolumn{4}{|c|}{ : Manitol } & & \multirow{2}{*}{\multicolumn{2}{|c|}{ SC }} & \multirow{2}{*}{\multicolumn{4}{|c|}{ : Simmon's Citrat }} & \\
\hline Ml & : Mal & & & & & & & & & & & \\
\hline
\end{tabular}


pneumoniae. Diketahui bahwa Klebsiella pneumoniae pada media gula-gula (glukosa, laktosa, manitol, maltosa, dan sukrosa) menimbulkan terjadinya fermentasi karbohidrat sehingga terjadi perubahan warna media menjadi kuning. Pada media SIM menunjukkan bahwa hanya terdapat pergerakan/ mutillity. Pada media simmons citrat terjadi perubahan warna media dari hijau menjadi biru, hal ini dikarenakan bakteri tersebut memiliki enzim spesifik yang membawa sitrat ke dalam selnya. Pada media MR terjadi perubahan warna menjadi warna merah setelah ditetesi dengan Methyl red yang disebabkan karena bakteri ini meragi asam campuran.

Escherichia coli dan Klebsiella pneumoniae terdapat pada sampel air outlet yang diteliti karena sampel air tersebut sangat rentan menyebarkan bakteri patogen yang disebabkan karena air danau yang terkontaminasi oleh feses manusia maupun hewan berdarah panas yang hidup disekitar danau dan outlet danau Sentani. Escherichia coli dan Klebsiella pneumoniae merupakan bakteri yang hidup pada usus manusia dan hewan berdarah panas sehingga penyebarannya dapat terjadi melalui feses manusia dan hewan berdarah panas tersebut.

Escherichia coli dan Klebsiella pneumoniae merupakan bakteri patogen yang dapat menyebabkan penyakit infeksi. Seberapa besar kemampuan bakteri untuk menyebabkan infeksi disebut virulensi. Penyakit infeksi akan timbul apabila terjadi ketidakseimbangan antara patogenitas bakteri dengan pertahanan tubuh manusia. Keberadaan Escherichia coli dalam usus manusia tidak dapat menyebabkan penyakit apabila daya tahan tubuh manusia normal. Untuk dapat menyebabkan penyakit infeksi, dibutuhkan dosis (jumlah) bakteri tertentu tergantung sifat patogen dan virulensi bakteri (PAMKI, 2008).

Escherichia coli dapat menyebabkan diare, memproduksi enterotoksin yang secara tidak langsung menyebabkan kehilangan cairan dan menginvasi lapisan epitelium dinding usus sehingga terjadi peradangan dan kehilangan cairan. Selain itu, E. coli merupakan penyebab 70$80 \%$ penyakit Infeksi Saluran Kemih (ISK) selain kelompok bakteri lain seperti Klebsiella, Proteus,
Enterobacter, Pseudomonal, Streptococcus dan golongan Staphylococcus (Drakeiron, 2008). Klebsiella pneuminiae merupakan penyebab penyakit pneumonia. Pneumonia adalah proses infeksi akut yang mengenai jaringan paru-paru (alveoli) (Anonimous, 2008).

Data yang diperoleh dari ketiga titik lokasi penelitian menunjukkan bahwa air keluaran (outlet) danau Sentani memiliki suhu yang sama yaitu $30^{\circ} \mathrm{C}$., $\mathrm{pH}$ netral, tetapi dengan kedalaman dan kecerahan perairan yang berbeda. E. coli merupakan bakteri yang tergolong ke dalam kelompok bakteri mesofil karena memiliki suhu optimum dalam pertumbuhannya yaitu $25^{\circ}-37^{\circ} \mathrm{C}$ (Waluyo, 2007). Sehingga suhu air keluaran (oulet) danau Sentani merupakan suhu yang sangat baik bagi pertumbuhan bakteri E. coli. Faktor lingkungan lain juga mendukung pertumbuhan jenis kelompok bakteri ini (Tabel 6).

Tabel 6. Nilai parameter lingkungan dari air keluaran (outlet) Danau Sentani.

\begin{tabular}{ccccc}
\hline $\begin{array}{c}\text { Titik } \\
\text { Sampel }\end{array}$ & \multicolumn{4}{c}{ Parameter } \\
\cline { 2 - 5 } & $\begin{array}{c}\text { Suhu } \\
\left({ }^{\circ} \mathrm{C}\right)\end{array}$ & $\mathrm{pH}$ & $\begin{array}{c}\text { Kedalaman } \\
\text { air }(\mathrm{cm})\end{array}$ & $\begin{array}{c}\text { Kecerahan } \\
\text { air }(\mathrm{cm})\end{array}$ \\
\hline A & 30 & 6,8 & 340 & 270 \\
B & 30 & 6,8 & 55 & 55 \\
C & 30 & 6,7 & 51 & 51 \\
\hline
\end{tabular}

\section{KESIMPULAN}

\section{Kesimpulan}

Dari hasil penelitian ini, maka dapat disimpulkan bahwa:

1. Terdapat bakteri Coliform dalam $100 \mathrm{ml}$ sampel air dari tiga titik pengambilan sampel sehingga air muara tidak layak untuk dikonsumsi.

2. Kadar kontaminasi bakteri Coliform dengan media BGLB pada titik A (daerah muara) adalah sebesar $9.300 \mathrm{MPN} / 100 \mathrm{ml}$, titik B (daerah antara muara dan sungai Jaifuri) adalah sebesar $4.300 \mathrm{MPN} / 100 \mathrm{ml}$ dan titik C (sungai Jaifuri) adalah sebesar $24.000 \mathrm{MPN} /$ $100 \mathrm{ml}$ sampel air. 
3. Terdapat perbedaan kadar kontaminasi Coliform antara daerah muara (titik A) yaitu sebesar 9.300 MPN/100 ml dan sungai Jaifuri (titik C) yaitu $24.000 \mathrm{MPN} / 100 \mathrm{ml}$ sampel air.

4. Terdapat bakteri Escherichia coli pada sampel yang diuji secara biokimia yaitu terbentuk gas dan terjadi perubahan warna media menjadi kuning, menghasilkan Indol, terdapat pergerakan (mutillity), tidak menyerap sitrat sehingga hasil negatif pada media simmon's citrat, dan tidak bereaksi pada media MRVP.

\section{Saran}

1. Masyarakat kampung Yokiwa dan kampung lainnya yang memanfaatkan air keluaran (outlet) Danau Sentani sebagai sumber air minum diharapkan agar melakukan pengolahan dan perebusan yang benar terhadap air sebelum dikonsumsi.

2. Perlu dibangunnya sarana air bersih yang lebih terjamin kualitas airnya agar dapat dimanfaatkan masyarakat di kampung Yokiwa.

\section{DAFTAR PUSTAKA}

Anonimous. 2008. Klebsiella pneumoniae. (online). (http:/ /72.14.235.132/search?q=cache:Gd0IaW_d 6ioJ:mikrobia2.files.wordpress.com/2008/05/kle bsiellapneumoniae.pdf+penyakit+karena+Klebsi ella + pneumoniae $\& \mathrm{~cd}=3 \& \mathrm{hl}=\mathrm{id} \& \mathrm{ct}=\mathrm{clnk} \& \mathrm{gl}=\mathrm{id} \& \mathrm{l}$ r=lang_id\&client=firefox-a). diakses: 5 Mei 2009

Badjoeri, M dan Lukman. 2007. Kelimpahan Bakteri Heterotrofik di Perairan Danau Sentani. Prosiding Seminar Nasional Breeding, Genetika dan Bioteknologi Perikanan.12 November. Kuta-Bali

Drakeiron. 2008. Info Infeksi Saluran Kemih. (online). (http://drakeiron.wordpress.com/2008/11/23/i nfo-isk/). diakses: 14 Mei 2009.

Irianto, K. 2006. Mikrobiologi Menguak Dunia Mikroorganisme Jilid 2. Yrama Widya. Bandung

Lukman dan H. Fauzi. 1991. Laporan Pra Survey Danau Sentani Irian Jaya, dan Wilayah Sekitarnya. Pusat Penelitian dan Pengembangan Limnologi Lembaga Ilmu Pengetahuan Indonesia. Bogor.

PAMKI. 2008. Pendapat Perhimpunan Dokter Spesialis Mikrobiologi Klinik Indonesia Tentang Adanya Bakteri Enterobacter sakazakii Dalam Susu Bubuk Formula. (online). (http://www.fk.unair.acid/ download/files/pendapat $\% 20$.Enterobacter $\% 20$ s akazakii_di\%20susu\%20bubuk\%20formula \%2003 032008_final.pdf). diakses: 14 Mei 2009.

Ramadhany, D dan Amiruddin. 2008. Uji Biokimia Mikroba. (online). (http://dydear.multiply.com/ journal/item/3/Uji_Biokimia_Mikroba). diakses: 5 Mei 2009.

Suriawiria, U. 1995. Pengantar Mikrobiologi Umum. Angkasa. Bandung.

Volk, W.A dan Wheeler M.F. 1990. Mikrobiologi Dasar Edisi kelima Jilid 2. Erlangga. Jakarta.

Waluyo, L. 2007. Mikrobiologi Umum. Edisi Revisi. UMM Press. Malang. 

JURNAL BIOLOGI PAPUA

ISSN: 2086-3314

Volume 1, Nomor 2

Oktober 2009

Halaman: 65-71 